\title{
CORPORATE GOVERNANCE, FIRM PERFORMANCE AND EXECUTIVE PAY: A COMPARISON OF DEFENSE AND NON- DEFENSE FIRMS
}

\author{
Bertrand Lemennicier *, Joël Hermet ${ }^{* *}$, \\ Duraisamy Palanigounder
}

* Corresponding author, University of Pantheon-Assas, IRGEI, Paris, France

Contact details: University of Pantheon-Assas (Paris 2), 75005, Paris, France ** Lycee de Mantes la Jolie, IRGEI, Paris, France

*** University of Madras, Chennai, India

OPEN ACCESS

How to cite this paper: Lemennicier, B., Hermet, J., \& Duraisamy, P. (2019). Corporate governance, firm performance and executive pay: A comparison of defense and non-defense firms. Corporate Governance and Sustainability Review, 3(2), 8-17. http://doi.org/10.22495/cgsrv3i2pl

Copyright $@ 2019$ The Authors

This work is licensed under a Creative Commons Attribution 4.0 International License (CC BY 4.0). https://creativecommons.org/licens es/by/4.0/

\section{ISSN Online: $2519-898 \mathrm{X}$} ISSN Print: 2519-8971

Received: 22.03 .2019 Accepted: 22.05.2019

JEL Classification: M120, L210, G30, G34

DOI: $10.22495 /$ cgsrv3i2pl

\begin{abstract}
This study analyses pay-performance relationship and pay structure of executives and tests whether the pay structure of CEOs differs across firms in the defense and non-defense sector using econometric methodology. The empirical results based on ordinary least squares, Probit and Tobit methods show that on an average, executives in the defense firms earn more than their counterparts in the non-defense sector. However, when we control for governance structure, firm performance and other characteristics, the difference in executives' remuneration vanishes. The important determinants of executive pay are the legal system, firm performance measured by Return on Assets (ROA), whether the CEO is also Chairman of the board, and size of the firm. The estimates of the determinants of restricted stock awards showed that firm performance, governance and other characteristics significantly influence the likelihood of obtaining restricted stock awards and also the value of the stock award.
\end{abstract}

Keywords: Corporate Governance, Executive Compensation, Firm Performance, Defense Industry

\begin{abstract}
Acknowledgements: This work is the outcome of a study commissioned and funded by the Delegation for Strategic Affairs of the French Ministry of Defense. It is managed by the Secretariat General for Administration (Economic Observatory of Defense), with the assistance of the Directorate General for Armaments. We thank APTUS society, represented by Daniel Coudroyer, for his moral and financial support, Sylvain Moura, Marc Antoine Kleinpeter Observatory of Defense (OED) of the Ministry of Defense for their material and intellectual inputs and Ingrid Deleuze the DGA for their valuable comments on the project report. The authors wish to thank Enrico Colombatto of ICER, Giovanni Ramello and participants of the doctoral seminar of the IEL (Institutions, Economics and Law) of the Collegio Carlo Alberto in Turin for their comments and suggestions.
\end{abstract}

\section{INTRODUCTION}

The question of how governance of firms can improve their performance has been widely discussed by economists over the past several decades. There is a voluminous theoretical and empirical literature examining the interrelationship between governance structure, firm performance and executive compensation. Shleifer and Vishny (1997) provide a comprehensive review of theoretical and empirical studies and the empirical evidence reported by them are based on the studies for USA, Germany, Japan and Russia. Subsequently, Barkema and Gomez-Mejia (1998) and Devers, Cannella, Reilly and Yoder (2007) reviewed the studies mostly relating to the Western world. A recent review by Sun, Zhao and Yang (2010) is primarily confined to studies on executive compensation in Asian countries. 
In this study, we focus on the impact of governance and firm performance on executive compensation in the defense firms in comparison with the firms from a "peer group" of non-defense sector. The operating environment of the firms in defense industry is different from those in other sectors. The main consumers of the defense products are the governments. The sale of defense equipment depends upon lobbying and negotiation. The demand for the goods produced by these firms also depends upon the governments' defense budget allocation which in turn is determined by internal and external security threats. The market for the goods produced by defense industry is not as competitive as that of any other industry and hence the defense firms may not be able to operate efficiently. We are not aware of any study examining the determinants of executive pay in the defense industry which is quite important in the context of ever-increasing budget allocation to the defense sector in many developed and developing countries. Hence this study would be a significant value addition to the existing literature.

The legal system may also influence executive compensation. It is believed that the "Anglo-Saxon laws" are more conducive to business and quick to respond to changing business environment than the "common laws" prevailing in many countries. We also examine whether Anglo-Saxon legal system has any impact on the executive compensation.

The rest of the paper is structured as follows: Section 2 reviews the theoretical and empirical literature pertaining to corporate governance and executive compensation and summarizes the stylized facts; Section 3 describes the data base; Section 4 presents the methodology and empirical model used in the study; Section 5 discusses the empirical results; finally, Section 6 reports the main limitations, implications and conclusions.

\section{LITERATURE REVIEW}

Several studies have examined theoretically as well as empirically the issues pertaining to Chief Executive Offer's (CEOs) pay or compensation ${ }^{1}$. We summarize and present the theoretical arguments and empirical evidence below.

\subsection{Firm performance and executive compensation}

Corporate governance deals with the ways in which the providers of finance to firms assure themselves of getting a return on their investment (Shleifer \& Vishny, 1997). The shareholders rely on corporate managers to adopt policies that maximize the value of their shares. However, managers may also engage in activities that maximize their own well-being. Thus, there is a conflict of interest between the investors and managers of the firm. This is what is widely referred to as principal-agent problem or agency model ${ }^{2}$. The essence of the agency problem is

\footnotetext{
Pay and compensation are used interchangeably and it refers to annual basic salary, bonus and other compensations such as stock-options etc., The measurement of executive's pay used in this study is given in Section 3. ${ }^{2}$ There are other modalities by which the managers are made to function in the interest of shareholders and not purely on their own personal interest (i) Hiring persons with high ethical values and who are loyal to the firm (ii) Well defined contractual arrangements for the decision making process (iii) Partly delegating the decision making powers to large shareholders to
}

the separation of ownership and control of the firm. In these situations, agency theory predicts that compensation policy will be designed to give the manager incentives to select and implement actions that increase shareholder wealth (Jensen \& Murphy, 1990a, 1990b). The agency model has been used to examine the pay-performance relationship of executives. The evidence is quite mixed. Some studies which examined cross sectional variation in executive compensation and performance of the firms report a positive relationship (Murphy, 1985, Benston, 1985). Studies by Core et al. (1999) and Rose and Shepard (1997) find that current as well as past-year firm performance positively and significantly influence CEO compensation, especially the stock-based compensation. The tests of payperformance sensitivity based on the changes in the remuneration of executives and change in the shareholders' wealth in current and previous period show a week positive or inverse relationship (Jensen \& Murphy 1990a, Griffith, 1999).

\subsection{Volatility of the stocks and executive pay}

Aggarwal and Samwick (1999) argue that the executives in firms with more volatile stock prices will have less performance-based compensation. The fixed share should therefore be sensitive to price volatility as a reflection of economic fluctuations. High volatility in share prices should motivate the CEOs to prefer a higher fixed component in their remuneration package. However, the type of contract the firms enter into with CEOs depends upon the firm's skill requirements, competition among firms and the acquired skills of the potential managers.

\subsection{Governance structure and executive pay}

The role of the governance structure on executive's compensation is studied by looking at the composition of the Board of Directors of firms. The Board plays an important role in the executive's compensation. The Board not only hires and fires executives but also monitors their performance and fixes their compensation. Several interesting findings emerge from the literature on this issue.

Studies show evidence that the executives' salary levels are higher if the CEO is also the chairman of the board (Crystal, 1991; Main, O'Reilly \& Wade, 1995; Core, Holthausen \& Larcker, 1999; Goyal \& Park, 2002). Crystal (1991) argues that if the CEO becomes the chairman of the board, then monitoring becomes more difficult, because the CEO essentially has the power to hire or remove other nonexecutive directors. Such board members take the role of passive advisors, especially on matters concerning CEO compensation. Main, O'Reilly, and Wade (1995) find that if the CEO is appointed before the other directors are, then compensation levels will be higher than they are if the CEO is appointed after the board of directors. They argue that when the CEO is also Chairman, he receives higher remuneration due to additional/greater

overcome the agency problem, Demsetz (1988) and (iv) Outsource the control to outsiders such as institutional investors, banks, mutual funds, etc. who are in the business. However, all these involve transaction costs and the solution is what Coase (1937) points out, that is, internalize the external transactions. 
responsibilities ${ }^{3}$. Evidence also shows that the composition of the board, that is, presence of more outside members to total members, has a negative influence on executive compensation. Although independence of the board increases with inclusion of outside members, the actual impact on decision making depends on the time taken to learn about the actual functioning of the firm which is usually longer compared to the inside directors of the firm (Duchin, Matsusaka, \& Ozbas, 2010) ${ }^{4}$. Core, Holthausen, and Larcker (1999) find that the proportion of non-executive directors is positively correlated with CEO compensation. However, Fama and Jensen (1983) argue that as the proportion of non-executive board members on the board increases, CEO compensation tends to fall because of better monitoring.

\subsection{Firm ownership pattern and executive remuneration}

Fama and Jensen (1983) report that combining ownership and control allows concentrated shareholders to exchange profits for private rents. Demsetz (1983) is also of the view that owners may choose non-pecuniary consumption and thereby draw scare resources away from profitable projects. On the other hand, Anderson and Reeb (2008) show evidence that family owned firms perform better than nonfamily firms and that family ownership provides an effective organizational structure. The findings of studies on the effect of family ownership on firm's performance are rather mixed. Rau, Werner, and Schell (2018) based on their study of firms in Germany find that innovation output decreases over the generations, but if the third and later generation owner-managers are not only legal owners but also have high levels of psychological ownership, then they are highly successful and innovative as their earlier generation of owners. A study of Italian wine companies by Marsigalia, Giovannini, and Palumbo (2019) shows that a long history of generational successions is likely to exert a positive influence on the firm's returns and also in terms of brand image, reputation and cumulative know-how. Thus, if family ownership improves firm's performance, then shareholdings of the family in the firm is expected to be positively related to executive pay.

\subsection{Wage contract and restricted stock awards}

The wage contract for the executives which involves risk sharing between shareholders and managers consists of two parts: a fixed part (basic salary) independent of fluctuations in output of the firm and a variable component comprising (i) bonus, commission and other incentives based on performance of the firm and (ii) stock options,

\footnotetext{
${ }^{3}$ Christensen, Kent and Stewart (2010) estimated the impact of the dual role of CEO and Chairman of the Board on the performance of the firm in Australia using performance indicators such as Tobin's $q$ and return on equity (ROE) or assets (ROA). However, the evidence is not conclusive. ${ }^{4}$ Many authors are skeptical about the likely impact of the independence of the board on the performance of the firm. Bhagat and Black, (2002) and Hermalin and Weisbach (1998) find no significant correlation between independence and sales performance of the firm (Cited in Duchin Matsusaka, and Ozbas, 2010)
}

golden parachutes, "restricted" awards, pension and other retirement benefits.

The composition of the compensation package of the executives is also equally important as the level of compensation depends on firm performance. It can be paid directly (via bonus/commission) or indirectly (via stock option). Studies show that the share of performance-based executive compensation has been increasing over the years and it ranges from one-half to five-sixth of the total compensation (Jensen \& Murphy, 1990a).

A common argument against stock option is that it is easier to hype stock price over a short period than to build a long-term value. Options are inherently speculative, and they can be exercised into cash when the share price is attractive. Option is just another form of currency and not highly sensitive to performance as measured by changes in market value of equity (Jensen \& Murphy, 1990a; Paul, 1992; Sloan, 1993).

In this study, we examine (i) pay-performance relationship and (ii) structure of pay of the executives, especially, the stock awards to executives, and their relationship with performance and governance of the firm. We also test whether there is any difference between firms in the defense sector and "peer group" firms from non-defense sector. The selection of firms from the two groups and data sources are discussed in the following section.

\section{DATA BASE}

The study uses data from two categories of firms namely defense and a peer group from non-defense sector. The Defense News, a weekly newspaper, publishes the top 100 defense companies every year based on revenue from defense sector and these top 100 companies of 2009 are selected for the study ${ }^{5}$. The reason for choosing the year 2009 is that it is the latest year for which the required data was available when the study was initiated. A group of 100 non-defense firms is also included as control group. Each defense firm provides a list of firms considered as "peer groups" in their "Proxy Statement" submitted to the US Securities and Exchange Commission (SEC) (www.sec.gov). From this list, one of the non-defense firms operating in the same country of the defense firm was randomly selected. The data for these 200 firms on firm characteristics, governance structure, market performance and CEOs remuneration were collected from Thomson Reuters for the year 2009. Some of the firms in the defense sector did not report executives' compensation and data for other variables used in this study in their annual reports submitted to the SEC. We could get all the required information only for 54 defense firms and hence the study is restricted to 108 firms, 54 in each of defense and non-defense categories. The sample of firms is spread over several countries, some from the Anglo-Saxon region and the rest from other

\footnotetext{
${ }^{5}$ The Defense News Top 100 for 2009 Annual survey reports was published on June 28, 2010. See http://special.defensenews.com/top100/charts/rank_2009.php (accessed on May 27, 2012).
} 
countries. The list of defense firms and the firms selected from the "peer group" non-defense firms and their geographical location are given in Appendix Table A.1

\section{METHODOLOGY AND EMPIRICAL MODEL}

Based on the review of literature discussed in Section 2, we specify the following empirical model to test the relationship between governance structure and firm performance on executive's compensation $^{6}$ :

$$
\begin{gathered}
\log (\text { CEO Pay })_{i}=\beta_{0}+\beta_{1}(\text { Defense })_{i}+\beta_{2}(\text { Anglo- } \\
{\text { Saxon })_{i}}_{i}+\beta_{3}(\text { Performance })_{i}+\beta_{4}(\text { Governance })_{i} \\
+\beta_{5} X_{i}+u_{i}, i=1, . . N(\text { firms })
\end{gathered}
$$

The dependent variable, namely CEOs pay consists of: (i) basic pay (fixed component) and (ii) variable component comprising of bonus, annual compensation, value of stock option and other benefits. We use two measures of the dependent variable namely basic pay and total pay. Following the human capital theory, a semi-logarithmic form is used to specify the executive wage or compensation function. The sample of firms are spread over several countries and hence the salary structure is likely to differ from country to country. We also specify the dependent variable as the share of variable components to total pay.

The explanatory variables include (i) a set of dummy variables for defense firms, Anglo-Saxon countries, and a set of variables capturing (ii) firm performance (ii) governance and (iii) control variables $(\mathrm{X})$.

The dummy variable for defense firms takes the value of 1 if the firm is from defense sector and 0 otherwise. This enables us to test whether there is pay difference among the executives of the defense and non-defense firms. The legal system in the Anglo-Saxon countries is believed to be more conducive for business environment. We test this by introducing a dummy variable for Anglo-Saxon countries which takes the value of 1 if the firm is in USA, Canada, UK and Ireland and 0 for firms from other countries (France, Germany, Norway, Sweden, Netherlands, Luxembourg, Italy, Japan and Singapore) where the common law prevails.

The firm's performance is measured using the ROA (Net Revenue/Total Assets) and Tobin's q measured by the ratio of market capitalization to the total value of assets as reported in the financial statements. The Tobin's q does not exert a statistically significant effect and hence it is not included in the final analysis. The variance of the share prices of the firm in the last five years is also included.

The variables representing governance structure are: (i) the share of outside members to total members in the board of directors and (ii) whether CEO is also Chairman of the board of directors.
A set of control variables (X) is included to capture the firm structure and the environment in which the firms are operating: They are (i) share of family ownership and (ii) firm size measured by number of workers ${ }^{7}$.

The "restricted stock award" is an incentive some firms offer to encourage the executives to work in the interest of the firm and the shareholders. The executives will take more risk in order to increase the performance of the firm. To study whether the firm's performance has any impact on the restricted stock awards, the following model is specified and estimated:

$$
\begin{gathered}
\text { (Stock Award })_{i}=\beta_{0}+\beta_{1}(\text { Defense })_{i}+\beta_{2}(\text { Anglo- } \\
\text { Saxon })_{i}+\beta_{3}(\text { Performance })_{i}+\beta_{4} \\
(\text { Governance })_{i}+\beta_{S_{i}}+u_{i}, i=1, \ldots N(\text { firms })
\end{gathered}
$$

The dependent variable namely restricted stock award is measured as (i) a dummy variable which takes the value of 1 if the CEO is given restricted stocks based on the performance of the firm and 0 otherwise and (ii) the value of the stock award in US dollars. The explanatory variables included in the model are the ones defined above.

The executive compensation - indent to be added model (equation 1) with log of salary and log of total compensation as dependent variables is estimated by ordinary least squares method. Only $49 \%$ of the firms in the sample are compensating the executives with restricted stock awards. The dependent variable in the stock option model (equation 2) is either a dichotomous variable (stock award dummy) or truncated variable (value of stock option). The appropriate methods for these specifications of the model are maximum likelihood Probit and Tobit methods which are applied in this study.

\section{DESCRIPTIVE ANALYSIS}

The average annual compensation received by the executives under the various components in the defense and non-defense firms and also for the combined sample of all firms are given in Table 1 . The executives in our sample received an annual compensation of US $\$ 6.8$ million during the year 2009. The defense firms pay a slightly higher remuneration (US \$7.2 million) than the non-defense firms (US \$6.3 million). The annual salary component to total pay is $13.6 \%$ and $15.4 \%$ in defense and non-defense firms respectively. Thus the defense firms pay more on variable component than the non-defense firms. The share of restricted stock option to total compensation is about $26 \%$ for the executives in both defense and non-defense firms.

\footnotetext{
${ }^{6}$ Testing pay-performance sensitivity, an implication of the agency theory a proposed in Jensen and Murphy (1990b), Garen (1994), Aggarwal and Sawmick (1999) and others, requires panel data and hence not attempted in this study.
}

7 The CEO characteristics such as education and tenure in the firm are also tried but found the effect is not statistically significant. As there is not much variation in the level of education of the executives, the effect of education turns out to be not significant. 
Table 1. Average compensation of executives in defense and non-defense firms during the year 2009

\begin{tabular}{|c|c|c|c|c|c|c|}
\hline \multirow[b]{2}{*}{ Compensation Type } & \multicolumn{2}{|c|}{ Defense } & \multicolumn{2}{|c|}{ Non-Defense } & \multicolumn{2}{|c|}{ All Firms } \\
\hline & $\begin{array}{c}\text { Amount (in } \\
\text { US \$) }\end{array}$ & $\%$ to Total & $\begin{array}{c}\text { Amount (in } \\
\text { US \$) }\end{array}$ & \% to Total & $\begin{array}{c}\text { Amount (in } \\
\text { US \$) }\end{array}$ & $\begin{array}{c}\% \text { to } \\
\text { Total }\end{array}$ \\
\hline Salary & 986779 & 13.6 & 980349 & 15.4 & 983564 & 14.5 \\
\hline Bonus & 711035 & 9.8 & 772945 & 12.1 & 741990 & 10.9 \\
\hline Other Remuneration & 86947 & 1.2 & 85617 & 1.3 & 86282 & 1.3 \\
\hline Total & 1784761 & 24.7 & 1838911 & 28.9 & 1811836 & 26.7 \\
\hline Restricted Stock Value & 1881543 & 26.0 & 1684575 & 26.5 & 1783059 & 26.2 \\
\hline All Other Compensation & 3563475 & 49.3 & 2839320 & 44.6 & 3201398 & 47.1 \\
\hline Total Annual Compensation & 7229780 & 100.0 & 6362806 & 100.0 & 6796293 & 100 \\
\hline
\end{tabular}

Source: Authors computation

The distribution of the total compensation of the executives are given in Figures 1.1 to 1.3 for all, defense and non-defense firms respectively. The distributions are skewed as we observe in any wage

distribution. The variance of the executives' pay of the defense firms are slightly higher than the nondefense firms.

Figure 1. The distribution of the total compensation of the executives

Figure 1.1. Distribution of executives annual total compensation

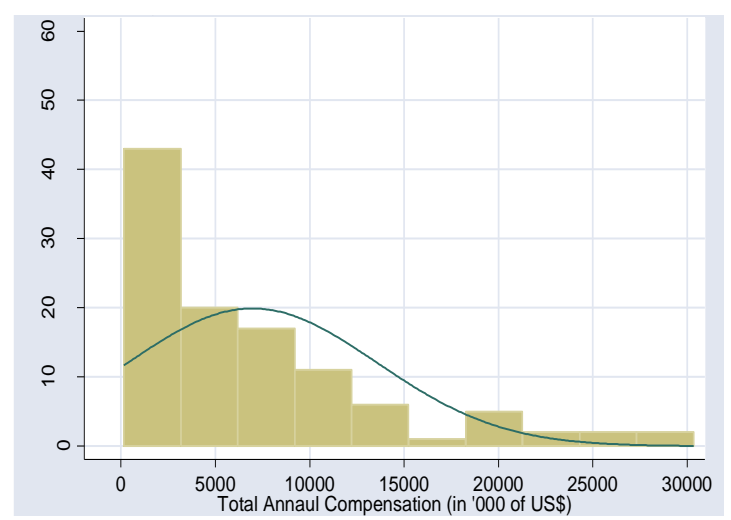

Figure 1.2. Distribution of executives annual total compensation - Defense Firms

Figure 1.3. Distribution of executives annual total compensation - Non - defense Firms

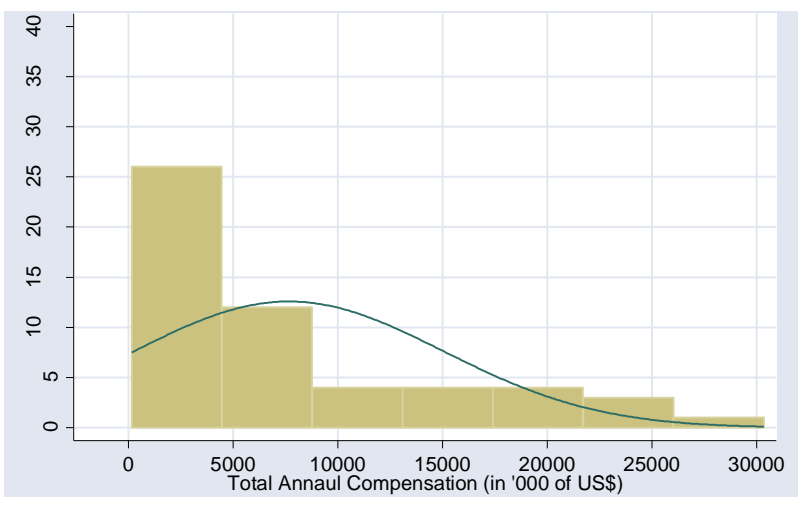

Source: Constructed using the authors' data base.

Table 2 gives the description of variables used in the regression analysis along with their means and standard deviation. The means of the variables indicate certain interesting findings. $61 \%$ of the firms are found to be offering restricted stock awards to their executives and it amounts to US \$ 1.8 billion. A majority (84\%) of the firms are from

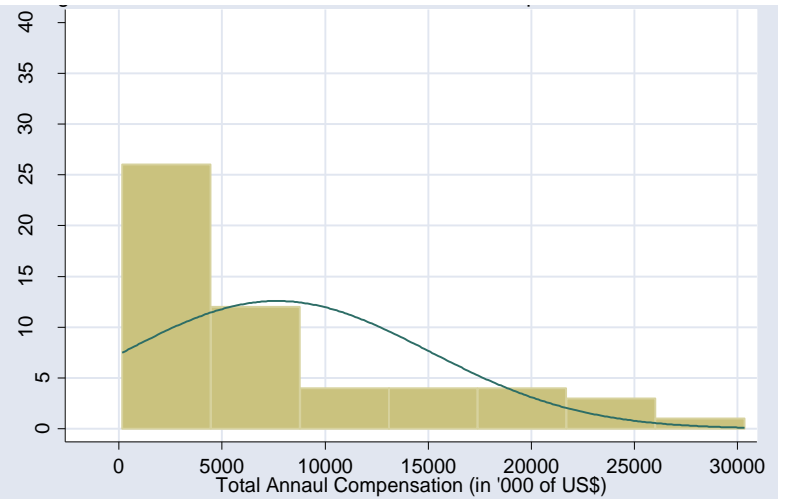


Table 2. Variable description and summary statistics

\begin{tabular}{|c|c|c|c|c|}
\hline Variables & Mean & Standard Deviation & Minimum & Maximum \\
\hline \multicolumn{5}{|c|}{ Dependent Variables } \\
\hline Logarithm of Salary & 13.67302 & 0.57413 & 11.28254 & 15.00943 \\
\hline Log (variable pay) & 14.95139 & 1.31539 & 9.284799 & 17.185 \\
\hline Log (total pay) & 15.31813 & 1.010811 & 11.9761 & 17.22773 \\
\hline Share of variable pay to total & 0.733659 & 0.211776 & 0 & 1 \\
\hline Restricted Stock (in US \$) & 1783059 & 2767401 & 0 & $1.47 \mathrm{E}+07$ \\
\hline Restricted Stock dummy $(1,0)$ & 0.611111 & 0.489771 & 0 & 1 \\
\hline \multicolumn{5}{|c|}{ Explanatory Variables } \\
\hline Defense Firm dummy $(1,0)$ & 0.5 & 0.502331 & 0 & 1 \\
\hline Anglo-Saxon Countries dummy $(1,0)$ & 0.842593 & 0.365882 & 0 & 1 \\
\hline \multicolumn{5}{|c|}{ Firm Performance } \\
\hline ROA (Return on Assets) & 6.589252 & 3.870308 & -1.25 & 23.95 \\
\hline Variation in Share Price 2004-2009 (Standard deviation) & 30.62945 & 81.96541 & 0.493939 & 766.0621 \\
\hline \multicolumn{5}{|c|}{ Governance } \\
\hline \% of External Members to Total Members of the Board & 0.423255 & 0.114734 & 0 & 0.666667 \\
\hline CEO cum Chairman - dummy & 0.518519 & 0.501986 & 0 & 1 \\
\hline \multicolumn{5}{|c|}{ Control variables } \\
\hline Number of employees & 49511 & 70099 & 1170 & 399409 \\
\hline $\log$ (number of employees) & 9.988452 & 1.367346 & 7.064759 & 12.89774 \\
\hline$\%$ of share owned by family & 2.70271 & 9.601551 & 0 & 50.55 \\
\hline \# of firms & 108 & & & \\
\hline
\end{tabular}

Source: Authors computation

\section{REGRESSION RESULTS AND DISCUSSION}

\subsection{The effect of governance and firm performance on executives pay}

The OLS estimates of the impact of firm performance and governance structure on the salary and total compensation of the executives are given in Table 3. The results show that excepting AngloSaxon dummy and logarithm of number of employees, the variables representing firm performance, governance and other control variables do not exert a statistically significant effect on salary (fixed component) but most of these variables have significant effects on total compensation. This may be because the variable component of remuneration, which is about $85 \%$ of the total compensation, depends mainly on the performance and governance structure of the firm.

The results suggest that there is no difference in the salary or total compensation of executives across defense and non-defense firms when we control for performance, governance and firm characteristics. The effect of Anglo-Saxon dummy variable is positive and statistically significant at $1 \%$ which implies that the salary and total compensation structure of the executives working in
Anglo-Saxon countries are higher compared to other countries where common law prevails.

The regression estimates of the total compensation equation indicate that the ROA has the expected positive and statistically significant at 1 percent level. This implies that as the performance of the firm improves, it leads to an increase in the remuneration of the executives. Another variable, the share price variation, which captures the performance of the firm in the stock market does not exert a significant effect on the compensation of the executives.

The results suggest that an increase in the share of external members in the Board of Governors does not increase the compensation of the executives. However, if the CEO is also the Chairman of the Board of Governors, the compensation of the executives increases by $42 \%$.

It is interesting to note that the size of the firm measured by the log of number of employees significantly (1\% level) increases the remuneration of the executives. However, as the share of family ownership increases, the payment to the executives declines. This is perhaps because ownership and control are not vastly separated in family owned firms. Overall, the variables included in the model for total compensation explains $63 \%$ of the total variation.

Table 3. Impact of firm performance and governance on executive salary and total compensation

\begin{tabular}{|c|c|c|c|c|}
\hline \multirow{2}{*}{ Explanatory Variables } & \multicolumn{2}{|c|}{ Log salary } & \multicolumn{2}{|c|}{ Log total compensation } \\
\hline & Coefficient & 't'value & Coefficient & t-value \\
\hline Defense dummy $(1,0)$ & -0.02461 & -0.25 & -0.05665 & -0.43 \\
\hline Anglo-Saxon Country dummy $(1,0)$ & 0.575815 & 3.59 & 1.077171 & 5.06 \\
\hline \multicolumn{5}{|c|}{ Firm Performance } \\
\hline ROA (Return on Assets) & 0.000847 & 0.07 & 0.035089 & 2.1 \\
\hline $\begin{array}{l}\text { Variation in Share Price 2004-2009 } \\
\text { (Standard deviation) }\end{array}$ & 0.000207 & 0.33 & -0.00103 & -1.23 \\
\hline \multicolumn{5}{|c|}{ Governance } \\
\hline \% of External Members to Total Members of the Board & -0.47807 & -0.95 & -0.01619 & -2.06 \\
\hline CEO cum Chairman dummy & 0.000847 & 0.07 & 0.367201 & 2.50 \\
\hline \multicolumn{5}{|c|}{ Control variables } \\
\hline $\log$ (number of employees) & 0.210037 & 5.65 & 0.446861 & 9.06 \\
\hline \% of share owned by family & 0.006696 & 1.13 & -0.52421 & -0.78 \\
\hline Constant & 11.18101 & 25.31 & 9.814916 & 16.76 \\
\hline Adjusted R-square & 0.322 & & 0.628 & \\
\hline F-ratio & 6.77 & & 21.50 & \\
\hline
\end{tabular}

Source: Authors' computation 


\subsection{Governance and performance on the executive's variable pay}

Next, we examine the effects of governance and firm performance on variable pay of the executives. The OLS estimates are given in Table 4 . The effects of the explanatory variables are as reported in the above analysis. The important difference is the effect of variation in the share price which significantly (at $10 \%$ or better) reduces the variable component of executive pay. An increase in the variation in share prices reduces the variable compensation of the executives.

Table 4. Impact of firm performance and governance on variable pay and share of variable to total pay of the executives, 2009

\begin{tabular}{|c|c|c|c|c|}
\hline \multirow{2}{*}{ Explanatory variables } & \multicolumn{2}{|c|}{ Log (variable pay) } & \multicolumn{2}{|c|}{ Share of variable pay to Total Pay } \\
\hline & Coefficient & 't' & Coefficient & 't' \\
\hline Defense dummy $(1,0)$ & -0.14217 & -0.76 & -0.05039 & -1.51 \\
\hline Anglo-Saxon Country dummy $(1,0)$ & 1.684895 & 5.44 & 0.160138 & 2.98 \\
\hline \multicolumn{5}{|c|}{ Firm Performance } \\
\hline ROA (Return on Assets) & 0.049113 & 2.14 & 0.006438 & 1.52 \\
\hline $\begin{array}{l}\text { Variation in Share Price 2004-2009 } \\
\text { (Standard deviation) }\end{array}$ & -0.00222 & -1.93 & -0.0004 & -1.91 \\
\hline \multicolumn{5}{|c|}{ Governance } \\
\hline \% of External Members to Total Members of the Board & -0.64516 & -0.67 & 0.16402 & 0.97 \\
\hline CEO cum Chairman - dummy & 0.496949 & 2.41 & 0.07213 & 1.94 \\
\hline \multicolumn{5}{|c|}{ Control variables } \\
\hline log(number of employees) & 0.474648 & 6.91 & 0.047803 & 3.84 \\
\hline \% of share owned by family & -0.02583 & -2.04 & -0.00685 & -3.45 \\
\hline Constant & 8.609038 & 10.58 & 0.022109 & 0.15 \\
\hline Adjusted R-square & 0.585 & & 0.438 & \\
\hline F-Ratio & 17.22 & & 10.45 & \\
\hline
\end{tabular}

Source: Authors' computation.

\subsection{The effects of firm performance and governance on stock option of the executives}

The maximum likelihood Probit and Tobit estimates of the determinants of the restricted stock option award to executives are given in Table 5. The Probit estimates show that the executives of the defense firm are less likely to receive restricted stock award compared to their counterparts in non-defense firms. The estimates show that the chance of receiving as well as the amount of restricted stock awards received by the executives in Anglo-Saxon countries is higher compared to non-Anglo-Saxon countries. The effect of RoA in the preferred Probit and Tobit models is not statistically significant even at the $10 \%$ level. However, the variation in the stock prices emerges as an important determinant of the probability of being offered restricted stock award and the amount of award and its coefficient is statistically significant at the $1 \%$ level. An increase in in the standard deviation of stock prices in the last five years by one percent reduces the chances of getting a restricted stock award by $1.2 \%$ which is about 25.3 thousand US dollars as per the Tobit estimates. The presence of external members in the board reduces while the CEO also being the Chairman of the board increases the value of restricted stock award. The size of the firm, measured by number of workers, has a statistically significant effect (at 5\% or above) on the restricted stock award which implies that the larger the size of the firm the higher the changes of obtaining and also higher the value of stock awards. An increase in family shareholding reduces the chances of getting restricted stock awards.

Table 5. The effect of firm performance and governance on the restricted stock award of the executives, 2009

\begin{tabular}{|c|c|c|c|c|c|c|}
\hline \multirow{3}{*}{ Explanatory Variables } & \multirow{2}{*}{\multicolumn{2}{|c|}{$\begin{array}{c}\begin{array}{c}\text { Restricted Stock Award } \\
\text { Dummy }\end{array} \\
\text { Probit } \\
\end{array}$}} & \multirow{2}{*}{\multicolumn{2}{|c|}{$\begin{array}{c}\text { Restricted Stock Value (in } \\
1000 \text { s of US \$) } \\
\text { OLS } \\
\end{array}$}} & \multirow{2}{*}{\multicolumn{2}{|c|}{$\begin{array}{c}\text { Restricted Stock Value (in } \\
1000 \text { s of US \$) } \\
\text { Tobit } \\
\end{array}$}} \\
\hline & & & & & & \\
\hline & Marginal Effect & ' $t$ ' & $\begin{array}{c}\text { Marginal } \\
\text { Effect }\end{array}$ & $t-$ & $\begin{array}{c}\text { Marginal } \\
\text { Effect }\end{array}$ & ' $t$ ' \\
\hline Defense dummy $(1,0)$ & -0.522353 & -3.4 & -175.5 & -0.37 & 227.9 & -1.54 \\
\hline Anglo-Saxon Country dummy $(1,0)$ & 0.7252462 & 4.16 & 2164.5 & 2.86 & 1535.3 & 4.55 \\
\hline \multicolumn{7}{|c|}{ Firm Performance } \\
\hline ROA (Return on Assets) & -0.0286367 & -1.54 & 109.8 & 1.84 & 7.7 & 0.28 \\
\hline $\begin{array}{l}\text { Variation in Share Price 2004-2009 } \\
\text { (Standard deviation) }\end{array}$ & -0.0120017 & -2.64 & -1.1 & -0.38 & -25.3 & -3.01 \\
\hline \multicolumn{7}{|c|}{ Governance } \\
\hline $\begin{array}{l}\text { \% of External Members to Total } \\
\text { Members of the Board }\end{array}$ & -0.3916011 & -0.52 & -4767.0 & -2.0 & -2765.2 & -2.33 \\
\hline CEO cum Chairman dummy & 0.3293381 & 1.93 & 1237.0 & 2.36 & 466.8 & 1.84 \\
\hline \multicolumn{7}{|c|}{ Control variables } \\
\hline Log (number of employees) & 0.1229511 & 1.97 & 991.2 & 5.64 & -21.2 & 5.88 \\
\hline \% of share owned by family & -0.0161274 & -1.67 & -33.4 & -1.19 & 489.0 & -1.23 \\
\hline Constant & & & -9062.2 & -4.34 & & \\
\hline Adjusted R-square/Pseudo R ${ }^{2}$ & 0.545 & & 0.383 & & 0.064 & \\
\hline F-ratio & & & 8.5 & & & \\
\hline
\end{tabular}

Note: The underlying marginal effects are computed from Probit model and presented in the table. In the case of Tobit model, the marginal effects are the expected value of the dependent variable conditional on being greater than zero.

Source: Authors' computation. 


\section{CONCLUSIONS}

The study examines the determinants of CEO's pay focusing on the role of governance structure, performance, size, family ownership pattern in top 54 defense firms and an equal number of firms in the "peer group" of non-defense firms in the world. The results based on descriptive and econometric analysis show that though the average pay received by the executives differs between defense and nondefense firms, when we control for the variation in governance, performance and other factors, there is no statistically significant difference in executive's pay between the two types of firms. The executive pay is higher in Anglo-Saxon countries compared to other countries with a common law.

The CEO who is also the Chairperson of the Board of Directors gets a larger variable component of total compensation and is more likely to get higher restricted stock awards. The increase in the share of external members in the board does not increase the salary (fixed component) but increases the restricted stock awards and thus total compensation.

The firm's performance, as measured by ROA, has a positive effect on the executive's total compensation. The variation in the share price during the last five years significantly reduces the value of restricted stock awards which implies that the CEOs are risk averse and prefer not to link their variable compensation with the stock market performance of the firms. The size of the firm has a positive effect while the increase in the family shareholding reduces the total compensation of the executives. The limitations of the study are the small sample size of 108 firms from the defense and nondefense sectors and the data pertain to the year 2009. Further research using data from 2009 to a more recent year with a larger sample size and employing panel data models would be more insightful and rewarding. Another aspect worthy of research is to examine how the political and socioeconomic settings of the countries influence the performance and executive pay of the defense firms.

The findings of our study imply that firms reward their executives based on their performance, return on assets, governance structure, legal system and country in which they operate. It can be inferred from the study that firms in the defense sector also remunerate their executives like the non-defense sector and this is amply evident from the econometric results that pay difference vanishes when we control for characteristics of firms. The methodology used in the study has scope for wider applications in this area.

\section{REFERENCES}

1. Adams, R., \& Mehran, H. (2003). Is corporate governance different for bank holding companies? Federal Reserve Bank of New York Economic Policy Review, 9(1), 123-41. https://doi.org/10.2139/ssrn.387561

2. Adams, R., Hermalin, B., \& Weisbach, M. (2010). The role of boards of directors in corporate governance: A conceptual framework and survey. Journal of Economic Literature, 48(1), 58-107. https://doi.org/10.1257/jel. 48.1.58

3. Aggarwal, R. K., \& Samwick, A. (1999). The other side of the trade-off: The impact of risk on executive compensation. Journal of Political Economy, 107(1), 65-105. https://doi.org/10.1086/250051

4. Aggarwal, R. K., \& Samwick, A. A. (2003). Why do managers diversify their firms? Agency reconsidered. Journal of Finance, 58(1), 71-118. https://doi.org/10.1111/1540-6261.00519

5. Anderson, R., \& Reeb, D. (2003). Founding-family ownership and firm performance: Evidence from the S\&P 500. The Journal of Finance, 58(3), 1301-1328. https://doi.org/10.1111/1540-6261.00567

6. Barkema, H. G., \& Gomez-Mejia, L. R. (1998). Managerial compensation and firm performance: A general research framework. Academy of Management Journal, 41(2), 135-145. https://doi.org/10.2307/257098

7. Benston, G. (1985). The self-serving management hypothesis: Some evidence. Journal of Accounting \& Economics, 7(1-3), 67-83. https://doi.org/10.1016/0165-4101(85)90028-X

8. Bhagat, S., \& Black, B. (2002). The non-correlation between board independence and long-term firm performance. Journal of Corporation Law, 27, 231-273.

9. Christensen, J., Kent, P., \& Stewart, J. (2010). Corporate governance and company performance in Australia. Australian Accounting Review, 20(4), 372-386. https://doi.org/10.1111/j.1835-2561.2010.00108.x

10. Claessens, S., \& Fan, P. (2002). Corporate governance in Asia: A Survey. International Review of Finance, 3(2), 71 103. https://doi.org/10.1111/1468-2443.00034

11. Core, J. E, Holthausen, R. W., \& Larcker, D. F. (1999). Corporate governance, chief executive officer compensation, and firm performance. Journal of Financial Economics, 51(3), 371-406. https://doi.org/10.1016/ S0304-405X(98)00058-0

12. Coase, R. (1937). The nature of the firm. Economica, 4, 386-405. https://doi.org/10.1111/j.14680335.1937.tb00002.x

13. Crystal, G. (1991). In search of excess: The overcompensation of American executives. New York: W.W. Norton

14. Demsetz, H. (1983). The structure of ownership and the theory of the firm. Journal of Law and Economics, 26(2), 375-390. https://doi.org/10.1086/467041

15. Demsetz, H. (1988). Ownership control and the firm. Basil Blackwell.

16. Devers, C. E., Cannella, A. A. J. R., Reilly, G. P., \& Yoder, M. E. (2007). Executive compensation: A multidisciplinary review of recent developments. Journal of Management, 33(6), 1016-1072. https://doi.org/10 $.1177 / 0149206307308588$

17. Duchin R., Matsusaka, J. G., \& Ozbas, O. (2010). When are outside directors effective? Journal of Financial Economics, 96(2), 195-214. https://doi.org/10.1016/j.jfineco.2009.12.004

18. Fama, E., \& Jensen, M. (1983a). Separation of ownership and control. Journal of Law and Economics, 26, 301325. https://doi.org/10.1086/467037

19. Fama, E., \& Jensen, M. (1983b). Agency problems and residuals claims. Journal of Law and Economics, 26, 327349. https://doi.org/10.1086/467038

20. Garen, J. E. (1994). Executive compensation and principal-agent theory. Journal of Political Economy, 102(6), 1175-99. https://doi.org/10.1086/261967

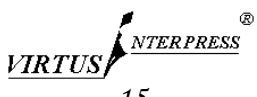


21. Griffiths, J. (1999). CEO ownership and firm value. Managerial and Decision Economics, 20(1), 1-8. https://doi.org/10.1002/(SICI)1099-1468(199902)20:1<1::AID-MDE914>3.0.CO;2-T

22. Hermalin, B., \& Weisbach, M. (1998). Endogenously chosen boards of directors and their monitoring of the CEO. American Economic Review, 88(1), 96-118.

23. Jensen, Michael C. \& K. J. Murphy, (1990a). CEO incentives: It's not how much you pay, but how. Journal of Applied Corporate Finance, 3, 36-49. https://doi.org/10.1111/j.1745-6622.1990.tb00207.x

24. Jensen, M., \& Murphy, K. J. (1990a). Performance pay and top management incentives. Journal of Political Economy, 98, 225-263. https://doi.org/10.1086/261677

25. Jensen, M., \& Murphy, K. J. (1990b). CEO incentives-It's not how much you pay, but how. Harvard Business Revenue, 68, 138-153.

26. Main, B. G. M., O'Reilly, C. A., \& Wade, J. (1995). The CEO, the board of directors and executive compensation: Economic and psychological perspectives. Industrial and Corporate Change, 4(2), 293-332. https://doi.org/10.1 093/icc/4.2.293

27. Macey, J., \& O’Hara, M. (2003). The corporate governance of banks. Economic Policy Review, 9(1). Retrieved from: https://ssrn.com/abstract $=795548$

28. Marsigalia, B., Giovannini, R., \& Palumbo, E. (2019). Family cumulative knowledge and firm's financial performance: An empirical investigation of the wine companies' governance. Corporate Governance and Sustainability Review, 3(1), 8-17. http://doi.org/10.22495/cgsrv3i1p1

29. Murphy, K. J. (1985). Corporate performance and managerial remuneration: An empirical analysis. Journal of Accounting \& Economics, 7(1-3), 11-41. https://doi.org/10.1016/0165-4101(85)90026-6

30. Paul, J. M. (1992). On the efficiency of stock based compensation. Review of Financial Studies, 5(3), 471-502. https://doi.org/10.1093/rfs/5.3.471

31. Rau, S. B., Werner, A., \& Schell, S. (2018). Psychological ownership as a driving factor of innovation in older family firms. Journal of Family Business Strategy. Retrieved from: https://doi.org/10.1016/j.jfbs.2018.03.001

32. Rose, N. L., \& Shepard, A. (1997). Firm diversification and CEO compensation: Managerial ability or executive entrenchment? RAND Journal of Economics, 28(3), 489-514. https://doi.org/10.2307/2556026

33. Shleifer, A., \& Vishny, R. (1997). A survey of corporate governance. The Journal of Finance, 52(2), 737-783. https://doi.org/10.1111/j.1540-6261.1997.tb04820.x

34. Sloan, R. G. (1993). Accounting earnings and top executive compensation. Journal of Accounting and Economics, 16(1-3), 55-100. https://doi.org/10.1016/0165-4101(93)90005-Z

35. Sun, S., Zhao, X., \& Yang, H. (2010). Executive compensation in Asia: A critical review and outlook. Asia Pac Journal of Management, 27(4), 775-802. https://doi.org/10.1007/s10490-010-9207-7 


\section{APPENDIX}

Table A.1. List of sample firms from defense and non-defense sector

\begin{tabular}{|c|c|c|c|c|}
\hline Serial no & Country & DEFENSE & Country & NON-DEFENSE (PEER GROUP) \\
\hline 1 & USA & Lockheed Martin & USA & Dow Chemical \\
\hline 2 & UK & BAE Systems & UK & Sainsbury \\
\hline 3 & USA & Boeing & USA & Procter \& gamble \\
\hline 4 & USA & Northrop Grumman & USA & Caterpillar \\
\hline 5 & USA & General Dynamics & USA & Johson controls \\
\hline 6 & USA & Raytheon Company & USA & 3M Company \\
\hline 7 & NL & EADS & Luxembourg & Arcelor Mittal \\
\hline 8 & Italy & Finmeccanica & Japan & Suzuki motor \\
\hline 9 & USA & L-3 Communications & USA & Danaher \\
\hline 10 & USA & United Technologies & USA & Johnson \& johsnon \\
\hline 11 & USA & SAIC & USA & Automatic data processing \\
\hline 12 & USA & ITT & USA & Emerson electronic \\
\hline 13 & USA & KBR & USA & The Shaw group \\
\hline 14 & USA & Honeywell & USA & Dupont \\
\hline 15 & USA & $\mathrm{CSC}$ & USA & Xerox \\
\hline 16 & USA & GE Aviation & USA & Chevron \\
\hline 17 & USA & URS & USA & AECOM \\
\hline 18 & USA & Textron & USA & Texas instrument \\
\hline 19 & UK & Rolls-Royce & UK & Sabmiller \\
\hline 20 & France & Safran & France & Rexel \\
\hline 21 & USA & ATK & USA & Agilent technologies \\
\hline 22 & USA & Harris & USA & Applied materials \\
\hline 23 & Germany & Rheinmetall & Germany & Gea group \\
\hline 24 & USA & Oshkosh & USA & Dover \\
\hline 25 & USA & Rockwell Collins & USA & Flowserve \\
\hline 26 & UK & Cobham & USA & Nacco \\
\hline 27 & UK & Babcock International Group & USA & Crane \\
\hline 28 & USA & CACI International & USA & Broadrige \\
\hline 29 & Sweden & Saab & Suède & Scania \\
\hline 30 & USA & Goodrich & USA & Parker Hannifin \\
\hline 31 & Japan & Mitsubishi Electric & Japan & Nippon Steel \\
\hline 32 & USA & ManTech International & USA & Unisys \\
\hline 33 & UK & QinetiQ Group & UK & Briggs \& Straton \\
\hline 34 & USA & Hewlett-Packard & USA & IBM \\
\hline 35 & UK & Serco & UK & Rentokil \\
\hline 36 & Singapore & Singapore Technologies Engineering Ltd & Singapore & Sembcorp \\
\hline 37 & France & Dassault Aviation & France & Legrand (Wendel) \\
\hline 38 & Norway & Kongsberg & Norway & AF gruppen \\
\hline 39 & UK & GKN & USA & Tomkins \\
\hline 40 & USA & Force Protection & USA & Milacron (en faillite depuis 2008-2009) \\
\hline 41 & USA & Jacobs Engineering & USA & Foster Wheeler \\
\hline 42 & USA & Fluor & USA & Murphy oil \\
\hline 43 & USA & VSE & USA & CPI international \\
\hline 44 & UK & Ultra Electronics Holdings & USA & Terradine \\
\hline 45 & UK & Meggitt & USA & Triumph \\
\hline 46 & UK & Chemring & USA & Graco \\
\hline 47 & USA & Teledyne Technologies & USA & Ametek \\
\hline 48 & USA & Curtiss-Wright & USA & Enpro industries \\
\hline 49 & Canada & $\mathrm{CAE}$ & Canada & SNC lavalin \\
\hline 50 & USA & Cubic & USA & CH2M hill \\
\hline 51 & USA & FLIR & USA & Barnes \\
\hline 52 & USA & $\mathrm{AAR}$ & USA & Cascade \\
\hline 53 & USA & SRA International & USA & ICF International \\
\hline 54 & Ireland & Accenture & Irland & $\mathrm{CRH}$ \\
\hline
\end{tabular}

